\title{
PENINGKATAN HASIL BELAJAR TEMA DAERAH TEMPAT TINGGALKU MELALUI METODE PERMAINAN BINGO PADA SISWA KELAS IV SDN 007 SUNGAI PINANG TAHUN PEMBELAJARAN 2018/2019
}

\author{
Siska Oktaviani, Muhammad Ikhsan, Nur Maghfira Firdausetia \\ Universitas Widya Gama Mahakam Samarinda \\ siskaavianii@gmail.com,ihsanborneogroup@gmail.com,firdddaaam@gmail.com
}

\begin{abstract}
ABSTRAK
This study intended to improve students learning outcomes on force and motion material using the bingo game. This research was Classroom Action Research (CAR) conducted in three cycles. The subjects of the study were 26 children, consisting of 16 male students and 10 female students. Data collection techniques with observation and documentation and test learning outcomes.

The results showed in the first cycle with an average value of 66, the second cycle an average value of 80.76, and the third cycle an average value of 90.38. The level of completeness in the first cycle was $38.46 \%$, in the second cycle was $76.92 \%$, and the third cycle increased to $92.30 \%$. Thus, the level of completeness from cycle I to cycle II rose $30.77 \%$, and cycle II to cycle III growth to $22.98 \%$. Using the bingo game can increase student activity from cycle I to cycle III. In cycle I, there are aspects of attention $61.5 \%$, activeness $38.4 \%$ and participation $46.1 \%$ have increased in cycle II on aspects of attention 73\%, activeness $57.6 \%, 61.5 \%$ participation and increased in cycle III, namely in the aspect of attention to $92.3 \%$ activeness to $84.6 \%$ and participation aspects to $80.75 \%$.

In the assessment, there are two namely the spiritual attitude and social attitude. There are 3 aspects of spiritual attitude, namely thankful behavior, praying before and after doing activities, and saying hello when entering and leaving the room. And there are 5 aspects of social attitude, namely discipline, care, confidence, courtesy, and responsibility. It was seen that from cycle I to cycle III has increased in both good and very good categories. In the first cycle skills assessment with a percentage of $42.30 \%$, cycle II with a percentage of $73.07 \%$, and cycle III with a percentage of 92.30 .
\end{abstract}

Keywords: Improved Learning Outcomes, Theme of the Area Where I Live, Bingo Game

\section{ABSTRAK}

Penelitian ini bertujuan untuk meningkatkan hasil belajar siswa kelas IV SDN 007 Sungai Pinang pada materi gaya dan gerak dengan menggunakan metode permainan bingo. Jenis penelitian ini adalah Penelitian Tindakan Kelas (PTK) yang dilaksanakan di SDN 007 Sungai Pinang. Penelitian ini dilaksanakan sebanyak tiga siklus. Subjek penelitian adalah siswa kelas IV yang berjumlah 26 anak, terdiri dari 16 siswa laki-laki dan 10 siswi perempuan. Teknik pengumpulan data dengan observasi dan dokumentasi serta tes hasil belajar.

Hasil penelitian menunjukkan pada siklus I dengan nilai rata-rata 66, siklus II nilai ratarata 80,76 , dan siklus III nilai rata-rata 90,38. Tingkat ketuntasan pada siklus I menjadi $38,46 \%$, pada siklus II menjadi 76,92\%, dan siklus III meningkat menjadi 92,30\%. Dengan demikian tingkat ketuntasan dari siklus I ke siklus II naik 30,77\%, dan siklus II ke siklus III naik menjadi $22,98 \%$. Menggunakan metode permainan bingo dapat meningkatkan aktivitas siswa dari siklus I ke siklus III yaitu pada siklus I terdapat aspek perhatian $61,5 \%$, keaktifan $38,4 \%$ dan partisipasi $46,1 \%$ mengalami peningkatan di siklus II pada aspek perhatian 73\%, keaktifan 57,6\%, partisipasi $61,5 \%$ dan meningkat di siklus III yaitu pada aspek perhatian menjadi 92,3\% keaktifan menjadi $84,6 \%$ dan aspek partisipasi menjadi 80,75\%.

Pada penilaian sikap siswa ada dua yaitu sikap spiritual dan sikap sosial. Sikap spiritual ada 3 aspek yaitu perilaku bersyukur, berdoa sebelum dan sesudah melakukan kegiatan, dan mengucap salam ketika masuk dan keluar ruangan. Dan sikap sosial ada 5 aspek yaitu disiplin, 
peduli, percaya diri, santun, dan tanggung jawab. Dilihat bahwa dari siklus I sampai siklus III mengalami peningkatan pada kategori baik dan sangat baik. Pada penilaian keterampilan siklus I dengan persentase $42,30 \%$, siklus II dengan persentase $73,07 \%$, dan siklus III dengan persentase 92,30 .

Kata kunci: Peningkatan Hasil Belajar, Tema Daerah Tempat Tinggalku, Metode Permainan Bingo

\section{PENDAHULUAN}

Pendidikan adalah tempat yang bertujuan mengembangkan potensi-potensi yang dimiliki siswa. Hal tersebut ada di dalam undang-undang No. 20 tahun 2003 tentang Sistem Pendidikan Nasional Bab I Pasal 1 (ayat 1) bahwa Pendidikan adalah usaha sadar dan terencana untuk mewujudkan suasana belajar dan proses pembelajaran agar peserta didik secara aktif mengembangkan potensi dirinya untuk memiliki kekuatan spiritual keagamaan, pengendalian diri, kepribadian, kecerdasan, akhlak mulia, serta keterampilan yang diperlukan dirinya, masyarakat, bangsa dan negara.

Menurut Elfachmi (2016) Pendidikan adalah usaha untuk mendapatkan pengetahuan, baik secara formal melalui sekolah maupun secara informal dari pendidikan di dalam rumah dan masyarakat. Elfachmi, (Redja Mudyahardjo, 2016) mengemukakan pendidikan adalah segala pengaruh yang diupayakan sekolah terhadap anak dan remaja yang diserahkan kepada sekolah agar mempunyai kemampuan yang sempurna dan berkesadaran penuh terhadap hubungan-hubungan dan tugas-tugas sosial mereka.

Pada kurikulum 2013 ini, guru diwajibkan mampu mengaitkan beberapa mata pelajaran menjadi pembelajaran yang terpadu, agar dapat memberikan beberapa pengalaman yang bermakna kepada peserta didik, dan peserta didik lebih bersemangat untuk mendapatkan pengalaman belajarnya, maka dari itu hal ini didukung dengan suasana belajar yang menyenangkan bagi peserta didik dengan menggunakan permainan dalam pembelajaran untuk meningkatkan hasil belajar dan juga mendorong semangat belajar peserta didik agar aktif belajar di dalam kelas.

Berdasarkan hasil observasi yang telah peneliti lakukan, guru kelas IV SDN 007 Sungai Pinang belum sepenuhnya menyelenggarakan proses pembelajaran menurut UU tersebut. Hal ini dilihat karena proses pembelajaran hanya berpusat kepada guru sedangkan potensi yang dimiliki peserta didik belum dikembangkan secara maksimal.

Pembelajaran tematik adalah pembelajaran yang memadukan berbagai mata pelajaran atau bidang studi dengan menggunakan tema tertentu, kompetensi dasar (mata pelajaran tertentu) tidak harus dicapai semuanya, dilaksanakan pada kelas awal, menekan pada pengalaman anak didik yang mengalami sendiri proses pembelajarannya Khadir \& Asrohah (2015). Berdasarkan hal itu maka peran guru sangat penting dalam penyampaian materi pelajaran IPA adalah usaha manusia dalam memahami alam semesta melalui pengamatan yang tepat pada sasaran, serta menggunakan prosedur dan dijelaskan menggunakan penalaran sehingga mendapatkan suatu kesimpulan Susanto (2013). 
Hasil wawancara yang dilakukan peneliti dengan guru kelas IV SDN 007 Sungai Pinang di Samarinda. Beliau menjelaskan bahwa 26 siswa kelas IV pada muatan pelajaran IPA sebagian besar tidak mencapai target KKM. Sekolah telah menetapkan KKM untuk muatan pelajaran IPA adalah 75. Pada kelas IV hanya 11 siswa $(42,30 \%)$ dari jumlah siswa kelas IV yang mampu mencapai KKM. Temuan tersebut tentu kurang dari harapan. Rendahnya hasil belajar muatan pelajaran IPA menunjukkan adanya penyebab yang mendasar khususnya berkaitan dengan hasil belajar siswa dan kemampuan guru dalam mengelola kegiatan pembelajaran.

Demi meningkatkan hasil belajar siswa dan partisipan siswa pada pemahaman materi khususnya muatan pelajaran IPA. Upaya perbaikan dirasa perlu karena hasil belajar dan semangat belajar sangat mempengaruhi ketuntasan belajar dan kenaikan kelas siswa.

Berdasarkan permasalahan di atas peneliti mencoba memberikan sebuah cara yang diharapkan mampu menarik semangat siswa dalam belajar dan terjadi peningkatan hasil belajar melalui metode permainan bingo. Metode permainan bingo adalah jenis pembelajaran yang dipadukan dengan permainan dan dapat diterapkan ketika siswa jenuh di tengah pembelajaran. Tujuannya yaitu menjadikan siswa lebih waspada dan memperhatikan sajian materi yang dikemas dalam permainan bingo, karena melibatkan aturan permainan, melibatkan alat bantu berupa kartu bingo dan kartu pertanyaan, serta melibatkan peran siswa di dalamnya. Menurut Aqib \& Murtadlo (2016) metode permainan bingo adalah tindakan kelas yang dilakukan oleh pendidik sebagai upaya untuk memecahkan masalah yang timbul di kelas. Selain itu dengan pemberian permainan di tengah pembelajaran dapat meningkatkan keantusiasan yang berdampak pada keaktifan siswa di kelas. Pemberian metode ini juga membantu siswa untuk lebih mudah mengingat materi dan memahami hal penting yang ada dalam materi pembelajaran. Oleh karena itu, metode permainan bingo dapat digunakan dalam pembelajaran tematik untuk meningkatkan hasil belajar siswa.

Berdasarkan permasalahan tersebut, peneliti mengambil judul "Peningkatan Hasil Belajar Tema Daerah Tempat Tinggalku Melalui Metode Permainan Bingo Pada Siswa Kelas IV SDN 007 Sungai Pinang Tahun Pembelajaran 2018/2019”.

\section{METODE}

Jenis penelitian ini adalah penelitian tindakan kelas (PTK), Penelitian tindakan kelas merupakan suatu jenis penelitian yang dilakukan oleh guru untuk memecahkan masalah pembelajaran di kelasnya. Hasil penelitian tidak seperti dalam penelitian tradisional yang hanya menghasilkan pengetahuan. Penelitian tindakan bersifat siklus yang terus-menerus dilaksanakan hingga mencapai target, yaitu : 1) perencanaan, 2) mengambil tindakan, 3) evaluasi atas tindakan dan seterusnya sampai dapat ditemukan tindakan yang efektif efisien.

Penelitian ini dilaksanakan di SDN 007 Sungai Pinang yang berlokasi di Jalan Jenderal Ahmad Yani RT. 17 Kecamatan Sungai Pinang Kota Samarinda, Kalimantan Timur 75117. Waktu penelitian dilaksanakan pada bulan April sampai bulan Mei semester genap tahun pembelajaran $2018 / 2019$. Adapun subjek penelitian ini adalah siswa kelas IV dengan jumlah siswa 26 orang yang terdiri dari 16 orang laki-laki dan 10 orang perempuan.

Penelitian ini dilaksanakan melalui empat tahap yaitu perencanaan, pelaksanaan, pengamatan dan refleksi. Penelitian ini dilaksanakan terdiri dari 3 siklus, di mana setiap siklus terdiri dari 2 kali pertemuan. Pertemuan pertama menyampaikan materi dan pertemuan kedua melakukan kegiatan tes evaluasi kepada siswa. 
Teknik pengumpulan data yang digunakan dalam penelitian ini adalah lembar observasi, tes hasil belajar, dan dokumentasi. Lembar observasi digunakan untuk mengamati aktivitas guru dan siswa selama penelitian. Tes hasil belajar digunakan untuk mengukur hasil belajar siswa setelah dilakukan tindakan. Dokumentasi digunakan untuk memperoleh keterangan atau data yang bersifat dokumentatif, dapat berupa foto dan arsip surat.

Pada penelitian ini menggunakan teknik analisis data deskriptif kualitatif dan deskriptif kuantitatif. Teknik analisis data deskriptif kualitiatif digunakan untuk menganalisis data dengan cara mendeskripsikan data yang diperoleh di lapangan. Sedangkan teknik analisis data deskriptif kuantitatif yang berupa angka atau rumus yaitu skor dari tes hasil belajar dan persentase peningkatan hasil belajar siswa dalam setiap siklus.

Pelaksanaan penelitian dengan menggunakan metode permainan bingo dikatakan berhasil jika siswa dapat memperoleh nilai di atas angka 70. Tetapi jika sebaliknya yang terjadi yaitu siswa yang memperoleh nilai 70 ke atas tidak mencapai $80 \%$ maka pembelajaran tersebut dikatakan belum tuntas dan penelitian dilanjutkan pada siklus selanjutnya, hal ini sesuai dengan Kriteria Ketuntasan Minimum (KKM) SDN 007 Sungai Pinang yang menjadi indikatornya sebagai tolak ukur dalam menyatakan bahwa pembelajaran yang berlangsung selama penelitian berhasil jika meningkatkan hasil belajar siswa, jika terjadi peningkatan rata-rata hasil tes untuk setiap siklus dari tingkat keberhasilan siswa dalam persen.

\section{HASIL PENELITIAN DAN \\ PEMBAHASAN}

\section{Hasil Penelitian}

Berdasarkan tes hasil belajar dengan menerapkan metode permainan bingo hasil belajar siswa mengalami peningkatan.
Peningkatan tersebut dapat dilihat dari penjabaran berikut.

Sebelum melaksanakan tindakan peneltian, terlebih dahulu peneliti melakukan observasi. Dari observasi yang dilakukan maka diperoleh dari data bahwa masalah yang dihadapi oleh guru selama kegiatan pembelajaran adalah kemauan dalam belajar yang rendah, dan siswa menjadi pasif dalam mengikuti kegiatan pembelajaran. Selain itu guru juga menjelaskan bahwa hasil belajar siswa pada muatan pelajaran IPA kurang maksimal. Adapun data yang diperoleh sebagai berikut:

Tabel 1 Nilai Awal Siswa

\begin{tabular}{|c|c|c|}
\hline Keterangan & $\begin{array}{c}\text { Jumlah } \\
\text { Siswa }\end{array}$ & Persentase \\
\hline Tuntas & 14 & $53,84 \%$ \\
\hline Tidak Tuntas & 12 & $46,15 \%$ \\
\hline \multicolumn{2}{|c|}{ Rata-rata } & 64,26 \\
\hline
\end{tabular}

Berdasarkan tabel di atas dapat dijabarkan bahwa dari 26 siswa kelas IV, terdapat 14 siswa atau $53,84 \%$ sudah mencapai nilai ketuntasan dalam penelitian, dan sebanyak 12 siswa atau $46,15 \%$ belum mencapai nilai ketuntasan dalam penelitian.

Setelah mendapatkan nilai awal siswa, maka peneliti melaksanakan tindakan siklus I. Pada siklus I ini guru menyampaikan materi gaya dan gerak. Adapun langkah-langkah rencana pelaksanaan pembelajaran yaitu pada tahap perencanaan, dilakukan pengamatan pembelajaran IPA dikelas IV A SDN 007 Sungai Pinang.

Pertama-tama menentukan materi pembelajaran selanjutnya menentukan tujuan pembelajaran dan merancang langkah-langkah pembelajaran muatan pelajaran IPA yang berupa rencana pelaksanaan pembelajaran (RPP) yang mengacu pada kurikulum 2013 sesuai dengan materi yang telah ditetapkan melalui permainan bingo, menyiapkan soal terkait muatan pelajaran ilmu pengetahuan alam (IPA) khususnya tentang materi gaya dan 
gerak untuk mengetahui data hasil belajar siswa, menyusun lembar kerja siswa (LKS) yang akan dipelajari kelompok/individu, lembar jawaban, dan lembar kegiatan permainan bingo yang terkait dengan materi gaya dan gerak, menyiapkan media, sumber belajar, lembar kerja siswa, menyiapkan lembar observasi siswa dan guru, menyiapkan lembar penilaian sikap dan keterampilan serta menyiapkan kamera untuk dokumentasi.

Pelaksanaan siklus I terdiri dari dua kali pertemuan. Pertemuan pertama dilaksanakan pada tanggal 16 April 2019, pertemuan kedua dilaksanakan pada tanggal 18 April 2019. Pada pertemuan pertama, guru menyampaikan materi, dan pertemuan kedua, guru melakukan kegiatan pembelajaran sambil bermain bingo dan di akhiri tes evaluasi. Hasil evaluasi siklus I dapat dilihat pada tabel berikut:

Tabel 2 Tes Hasil Belajar Siklus I

\begin{tabular}{|c|c|c|}
\hline Keterangan & $\begin{array}{c}\text { Jumlah } \\
\text { Siswa }\end{array}$ & Persentase \\
\hline Tuntas & 10 & $38,46 \%$ \\
\hline Tidak Tuntas & 16 & $61,53 \%$ \\
\hline \multicolumn{2}{|c|}{ Rata-rata } & 66 \\
\hline
\end{tabular}

Berdasarkan tabel di atas dapat dijabarkan bahwa dari 26 siswa kelas IV, terdapat 10 siswa atau $38,46 \%$ sudah mencapai nilai ketuntasan dalam penelitian, dan sebanyak 16 siswa atau $61,53 \%$ belum mencapai nilai ketuntasan dalam penelitian.

Hasil belajar pada siklus I juga dinilai dari sikap spiritual, sikap sosial, dan nilai keterampilan. Pada penilaian sikap dari 26 siswa yang memiliki sikap spiritual dikategorikan baik ada 16 orang dan dikategorikan sangat baik ada 10 orang. Sedangkan sikap sosial dikategorikan cukup ada 2 orang, dikategorikan baik ada 20 orang, dan yang dikategorikan sangat baik ada 4 orang. Adapun nilai keterampilan siswa diperoleh dengan rata-rata $42,30 \%$.

Pada aktivitas siswa siklus I dapat diketahui bahwa hasil aspek perhatian ada 16 siswa dengan persentase sebesar $61,5 \%$, hasil aspek keaktifan ada 10 siswa dengan persentase sebesar 38,4\%, dan aspek partisipasi ada 12 siswa dengan persentase sebesar 46,1\%. Untuk aktivitas guru siklus I didapat skor 42 dengan persentase $70 \%$, dan aspek yang cukup baik ada 6 serta aspek yang baik ada 6 ..

Setelah selesai melaksanakan kegiatan pembelajaran dan observasi, guru melanjutkan ke tahap refleksi sebagai bahan pertimbangan dalam melaksanakan siklus II. Berdasarkan data yang diperoleh selama pelaksanaan siklus I menunjukkan perolehan hasil belajar IPA menggunakan permainan bingo telah mengalami peningkatan pada saat data awal hasil belajar siswa mencapai $34,61 \%$ dengan nilai rata-rata 60,84 dan pada siklus I meningkat menjadi 38,46\% dengan nilai rata-rata 66,00 . Ada peningkatan dengan menerapkan permainan bingo saat pembelajaran berlangsung. Dengan adanya kendala-kendala yang didapat pada siklus I maka peneliti melanjutkan penelitian ke siklus II.

Tahap perencanaan pada siklus II dilaksanakan sama seperti pada tahap perencanaan siklus I, yaitu menentukan materi pembelajaran selanjutnya menentukan tujuan pembelajaran dan merancang langkah-langkah pembelajaran muatan pelajaran IPA yang berupa rencana pelaksanaan pembelajaran (RPP) yang mengacu pada kurikulum 2013 sesuai dengan materi yang telah ditetapkan melalui permainan bingo, menyiapkan soal terkait muatan pelajaran ilmu pengetahuan alam (IPA) khususnya tentang materi gaya dan gerak untuk mengetahui data hasil belajar siswa, menyusun lembar kerja siswa (LKS) yang akan dipelajari kelompok/individu, lembar jawaban, dan lembar kegiatan permainan bingo yang terkait dengan materi gaya dan gerak, menyiapkan media, sumber belajar, lembar kerja siswa, menyiapkan lembar observasi siswa dan guru, menyiapkan lembar penilaian sikap dan keterampilan serta menyiapkan kamera untuk dokumentasi. 
Pelaksanaan siklus II terdiri dari dua kali pertemuan. Pertemuan pertama dilaksanakan pada tanggal 24 April 2019, pertemuan kedua dilaksanakan pada tanggal 25 April 2019. Pada pertemuan pertama, guru menyampaikan materi, dan pertemuan kedua, guru melakukan kegiatan pembelajaran sambil bermain bingo dan di akhiri tes evaluasi. Hasil evaluasi siklus II dapat dilihat pada tabel berikut:

Tabel 3 Tes Hasil Belajar Siklus II

\begin{tabular}{|c|c|c|}
\hline Keterangan & $\begin{array}{c}\text { Jumlah } \\
\text { Siswa }\end{array}$ & Persentase \\
\hline Tuntas & 20 & $76,92 \%$ \\
\hline Tidak Tuntas & 6 & $23,07 \%$ \\
\hline \multicolumn{2}{|c|}{ Rata-rata } & 80,76 \\
\hline
\end{tabular}

dijabarkan bahwa dari 26 siswa kelas IV, terdapat 20 siswa atau $76,92 \%$ sudah mencapai nilai ketuntasan dalam penelitian, dan sebanyak 6 siswa atau $23,07 \%$ belum mencapai nilai ketuntasan dalam penelitian.

Hasil belajar pada siklus II juga dinilai dari sikap spiritual, sikap sosial, dan nilai keterampilan. Pada penilaian sikap dari 26 siswa yang memiliki sikap spiritual dikategorikan baik ada 13 orang dan dikategorikan sangat baik ada 13 orang. Sedangkan sikap sosial dikategorikan baik ada 20 orang, dan yang dikategorikan sangat baik ada 6 orang. Adapun nilai keterampilan siswa diperoleh dengan rata-rata $73,07 \%$.

Pada aktivitas siswa siklus II dapat diketahui bahwa hasil aspek perhatian ada 19 siswa dengan persentase sebesar $73 \%$, hasil aspek keaktifan ada 15 siswa dengan persentase sebesar $57,6 \%$, dan aspek partisipasi ada 16 siswa dengan persentase sebesar $61,5 \%$. Untuk aktivitas guru siklus II didapat skor 50 dengan persentase $83,3 \%$, dengan aspek yang baik ada 10 dan aspek yang sangat baik ada 2 .

Setelah selesai melaksanakan kegiatan pembelajaran dan observasi, guru melanjutkan ke tahap refleksi sebagai bahan pertimbangan dalam melaksanakan siklus II. Berdasarkan data yang diperoleh selama pelaksanaan siklus I menunjukkan perolehan hasil belajar IPA menggunakan permainan bingo telah mengalami peningkatan pada saat siklus I hasil belajar siswa mencapai $38,46 \%$ dengan nilai rata-rata 66 dan pada siklus II meningkat menjadi 76,92\% dengan nilai rata-rata 80,76 . Peningkatan terjadi dengan menerapkan permainan bingo saat pembelajaran berlangsung. Dengan adanya kendala yang didapat pada siklus II maka peneliti memperbaiki pada siklus berikutnya.

Tahap perencanaan pada siklus III yaitu menentukan materi pembelajaran selanjutnya menentukan tujuan pembelajaran dan merancang langkahlangkah pembelajaran muatan pelajaran IPA yang berupa rencana pelaksanaan pembelajaran (RPP) yang mengacu pada kurikulum 2013 sesuai dengan materi yang telah ditetapkan melalui permainan bingo, menyiapkan soal terkait muatan pelajaran ilmu pengetahuan alam (IPA) khususnya tentang materi gaya dan gerak untuk mengetahui data hasil belajar siswa, menyusun lembar kerja siswa (LKS) yang akan dipelajari kelompok/individu, lembar jawaban, dan lembar kegiatan permainan bingo yang terkait dengan materi gaya dan gerak, menyiapkan media, sumber belajar, lembar kerja siswa, menyiapkan lembar observasi siswa dan guru, menyiapkan lembar penilaian sikap dan keterampilan serta menyiapkan kamera untuk dokumentasi.

Pelaksanaan siklus III terdiri dari dua kali pertemuan. Pertemuan pertama dilaksanakan pada tanggal 2 Mei 2019, pertemuan kedua dilaksanakan pada tanggal 3 Mei 2019. Pada pertemuan pertama, guru menyampaikan materi, dan pertemuan kedua, guru melakukan kegiatan pembelajaran sambil bermain bingo dan di akhiri tes evaluasi. Hasil evaluasi siklus III dapat dilihat pada tabel berikut:

Tabel 4 Tes Hasil Belajar Siklus III 


\begin{tabular}{|c|c|c|}
\hline Keterangan & $\begin{array}{c}\text { Jumlah } \\
\text { Siswa }\end{array}$ & Persentase \\
\hline Tuntas & 24 & $92,30 \%$ \\
\hline Tidak Tuntas & 2 & $7,69 \%$ \\
\hline \multicolumn{2}{|c|}{ Rata-rata } & 90,38 \\
\hline
\end{tabular}

Berdasarkan tabel di atas dapat dijabarkan bahwa dari 26 siswa kelas IV, terdapat 24 siswa atau $92,30 \%$ sudah mencapai nilai ketuntasan dalam penelitian, dan sebanyak 2 siswa atau 7,69\%. Pada siklus III hasil belajar lebih meningkat dari siklus II dan $>80 \%$ siswa telah mencapai nilai ketuntasan kriteria minimum.

Hasil belajar pada siklus III juga dinilai dari sikap spiritual, sikap sosial, dan nilai keterampilan. Pada penilaian sikap dari 26 siswa yang memiliki sikap spiritual semua siswa dikategorikan sangat baik. Sedangkan sikap sosial dikategorikan baik ada 6 orang, dan yang dikategorikan sangat baik ada 20 orang. Adapun nilai keterampilan siswa diperoleh dengan ratarata $92,30 \%$.

Tahap observasi pada siklus III dilaksanakan observasi aktivitas siswa dan peneliti mengawasi jalannya tes akhir siklus serta memperhatikan jalannya tes akhir siswa dalam mengerjakan soal. Selesai pelaksanaan tes peneliti melakukan koreksi lembar jawaban siswa hasil tes pertemuan di akhir siklus III.

Berdasarkan data yang diperoleh dalam pelaksanaan siklus III menunjukkan adanya peningkatan hasil belajar siswa pada tema 8 muatan pelajaran IPA. Sebesar $92,30 \%$ siswa mencapai nilai $\geq 70$ dengan predikat Baik Sekali. Dari hasil tersebut, maka penelitian ini dinyatakan berhasil dan penelitian ini dihentikan setelah melaksanakan siklus III.

\section{Pembahasan}

Berdasarkan data yang diperoleh dalam melaksanakan penelitian menunjukkan bahwa siklus I sampai siklus III memiliki peningkatan, terlihat dari hasil belajar dengan menggunakan metode permainan bingo dapat meningkatkan hasil belajar siswa kelas IV SDN 007 Sungai Pinang. Hal ini menunjukkan bahwa penggunaan metode dalam pembelajaran dapat menarik perhatian siswa sehingga dapat meningkatkan hasil belajar siswa.

Peningkatan hasil belajar siswa dapat dilihat dari rata-rata kelas dan persentase ketuntasan yang diperoleh selama penelitian. Peningkatan tersebut dapat dilihat pada grafik berikut:

Gambar 1. Grafik Persentase Perbandingan

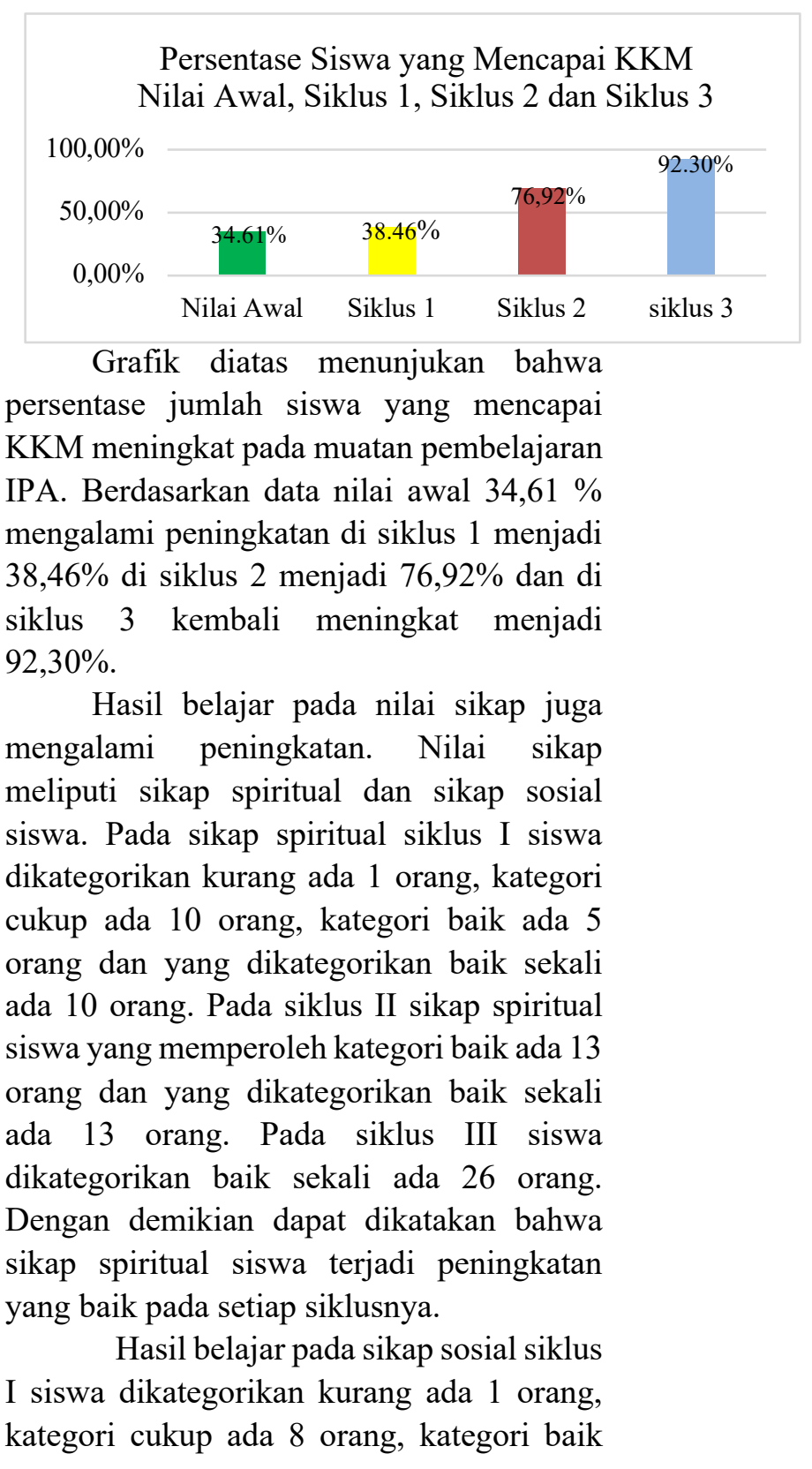


ada 9 orang dan yang dikategorikan baik sekali ada 8 orang. Pada siklus II siswa dikategorikan baik ada 14 orang dan yang dikategorikan baik sekali ada 12 orang. Pada siklus III siswa yang dikategorikan baik ada 4 orang dan kategori baik sekali ada 22 orang. Hal ini menunjukkan bahwa

aspek sikap sosial siswa mengalami peningkatan yang baik pada setiap siklus.

Hasil penelitian juga menunjukkan bahwa penerapan metode permainan bingo juga dapat meningkatkan keterampilan siswa. Hal ini dibuktikan dengan nilai ratarata keterampilan siswa pada siklus I yaitu 60, meningkat pada siklus II dengan nilai rata-rata 81,92 , kemudian meningkat pada siklus III dengan nilai rata-rata 79,23.

Berdasarkan hasil evaluasi selama pelaksanaan siklus I, siklus II, dan siklus III, hasil tindakan yang diberikan peneliti selama pembelajaran tema daerah tempat tinggalku tentang gaya dan gerak melalui metode permainan bingo yang diterapkan pada saat pembelajaran telah berhasil. Serta dapat dikatakan bahwa dengan menggunakan metode permainan bingo hasil belajar siswa kelas IV SDN 007 Sungai Pinang mengalami peningkatan.

\section{KESIMPULAN DAN SARAN}

Berdasarkan hasil penelitian pada bab sebelumnya, disimpulkan bahwa melalui metode permainan bingo dapat meningkatkan hasil belajar IPA materi gaya dan gerak pada siswa kelas IV SDN 007 Sungai Pinang. Peningkatan hasil belajar dapat dilihat dari persentase nilai awal yaitu $34,61 \%$ dengan nilai rata-rata 60,84 , pada siklus I 38,46\% dengan nilai rata-rata 66 , dan pada siklus II meningkat menjadi $76,92 \%$ dengan nilai rata-rata 80,76 , dan kembali meningkat pada siklus III menjadi $92,30 \%$ dengan nilai rata-rata 90,38 sehingga mencapai ketuntasan belajar mencapai $92,30 \%$.

Pada nilai afektif siswa yakni dinilai dari sikap spiritual dan sikap sosial, 26 siswa yang memiliki sikap spiritual dari siklus I ke siklus III berada pada kategori baik dan sangat baik. Sedangkan sikap sosial siklus I ada 24 siswa berada pada kategori baik dan sangat baik, kategori cukup ada 2 siswa, siklus II kesiklus III 26 siswa berada pada kategori baik dan sangat baik.

Pada nilai psikomotorik siswa yakni dinilai dari keterampilan dalam bekerjasama untuk mendapatkan bingo, pada siklus I nilai rata-rata adalah 60 dengan persentase $42,30 \%$. Pada siklus II nilai rata-rata adalah 81,92 dengan persentase $73,07 \%$. Dan pada siklus III nilai rata-rata adalah 79,23 dengan persentase $92,30 \%$.

Peningkatan pada aktivitas siswa dapat dilihat dari siklus I dengan aspek perhatian $61,5 \%$, keaktifan $38,4 \%$, dan partisipasi $46,1 \%$ mengalami peningkatan disiklus II pada aspek perhatian $73 \%$, keaktifan $57,6 \%$, patisipasi $61,5 \%$ dan mengalami peningkatan kembali pada siklus III yaitu pada aspek perhatian menjadi 92,3\% keaktifan menjadi $84,6 \%$ dan aspek partisipasi menjadi $80,75 \%$.

Berdasarkan kesimpulan di atas, ada beberapa saran yang dapat dipergunakan sebagai bahan pertimbangan dalam melaksanakan kegiatan pembelajaran yaitu sebagai berikut:

1) Bagi Guru

Bagi guru yang tertarik menggunakan metode permainan bingo ini diharapkan sebelum menerapkan guru harus mempersiapkan semua alat dan bahan serta yang terpenting adalah memperhatikan karakteristik atau gaya belajar siswa sehingga dapat menggunakan metode permainan bingo dengan maksimal.

2) Bagi penulis/peneliti

Bagi peneliti yang hendak menggunakan metode pembelajaran ini baiknya dapat digunakan sebagai salah satu bahan rujukan untuk melakukan penelitian yang serupa sehingga dapat meningkatkan hasil belajar siswa menjadi lebih baik, diharapkan untuk melakukan pemahaman terlebih dahulu tentang metode pembelajaran ini, serta menyesuaikan 
dengan materi pembelajaran dengan metode permainan bingo sehingga mendapatkan perolehan hasil yang maksimal sesuai dengan yang diharapkan.

Demikian penelitian tindakan kelas yang telah peneliti laksanakan, semoga bermanfaat bagi kita semua dan marilah kita menjadi guru yang kreatif sehingga dapat menciptakan generasi penerus bangsa yang berpikir kreatif.

\section{DAFTAR PUSTAKA}

Elfachmi, A. K. (2016). Pengantar Pendidikan. (A. Maulana, Ed.). Pamulang: Erlangga.

Khadir, \& Asrohah. (2015). Pembelajaran Tematik. Jakarta: PT. RajaGrafindo
Persada.

Susanto, A. (2013). Teori Belajar dan Pembelajaran di Sekolah Dasar. Jakarta: Kencana Prenada Group.

Aqib, Z., \& Murtadlo, A. (2016). Kumpulan Metode Pembelajaran Kreatif dan Inovatif. Bandung: CV Yrama Widya.

Djamarah, S. B. (2010). Guru Dan Anak Didik Dalam Interaksi Edukatif. Jakarta: PT. Rineka Cipta.

Estina, Ekawati, \& Sumaryatna. (2011). Pengembangan Instrumen Penilaian Pembelajaran Matematika SD/SMP. Yogyakarta: LPPPPTK Matematika. 